\title{
Personality Type Based Pumping-HR Model Toward Working Targets of The Civil Service
}

\author{
Amir Tengku Ramly and Didong Suherbi \\ Ibn Khaldun University, Indonesia \\ E-mail: amir.tengkuramly@uika-bogor.ac.id
}

\begin{abstract}
Personality is one of the factors that will affect employee performance. Civil Servants (PNS) who have individual personalities such as introverts and or extroverts can affect employee performance at certain levels. This study shows that employee personality affects their performance. Also, to examine the effect of employee personality on performance based on SKP (Employee Performance Targets). The results showed that there were significant differences between personality types on employee performance. It is found that the kind of personality Extrovert = Introvert produces the best average return based on the SKP evaluation results. In contrast, Extrovert's personality type provides the lowest average in the performance of Civil Servants, in the Agriculture Office of the City of Bogor. The excellent performance in the Regional Work Unit (SKPD), it is recommended to place employees with extrovert $=$ introvert personality types, especially in essential positions.
\end{abstract}

Keywords: Personality, Performance, Introvert, Extrovert, Pumping-HR Model.

\begin{abstract}
Abstrak: Kepribadian merupakan salah satu faktor yang akan mempengaruhi kinerja karyawan. Pegawai Negeri Sipil (PNS) yang memiliki kepribadian tertentu seperti introvert dan atau ekstrovert dapat mempengaruhi kinerja karyawan pada level tertentu. Penelitian ini memperlihatkan bahwa kepribadian karyawan mempengaruhi terhadap kinerja mereka. Penelitian ini juga untuk menguji pengaruh kepribadian pegawai terhadap kinerja berbasis pada SKP (Sasaran Kinerja Pegawai). Metode penelitian kuantitative melalui uji regresi ANOVA, BNT dan dummy. Hasil penelitian menunjukkan bahwa ada perbedaan yang signifikan antara tipe kepribadian terhadap kinerja karyawan. Ditemukan bahwa tipe kepribadain Ekstrovert sama dengan Introvert menghasilkan rata-rata kinerja terbaik berdasarkan hasil evaluasi SKP. Sedangkan tipe kepribadian Extrovert menghasilkan rata-rata terendah pada kinerja Pegawai Negeri Sipil, di dinas Pertanian Kota Bogor. Untuk menghasilkan kinerja yang baik di SKPD (Satuan Kerja Regional), disarankan untuk menempatkan karyawan dengan tipe kepribadian ekstrovert = introvert, terutama di posisi penting.
\end{abstract}

Kata Kunci: Kepribadian, kinerja, introvert, ekstrovert, Pumping-HR Model.

\section{INTRODUCTION}

Personality is the best factor to be used to predict employee performance. This variable can be used to predict employee performance contextually, although it does not support employee performance technically (Sen and Dulara, 2017). The relationship 
between personality and one's performance is influence by circumstances and the tendency of individuals to behave differently and deviate from characteristics when outside the work environment (Judge and Zapata, 2015).

Jung divides human personality into two types, introverted or extroverted (Kurniawan and Stanislaus, 2016). An introvert who is calm prefers to withdraw and is less friendly. He tends to plan before doing something, keeping his feelings under constant control. Very sensitive to punishment rather than gifts. An extrovert easily socializes, has many friends, takes or seizes opportunities, often pays attention to what is happening outside of himself, his actions are not thought of in advance, generally like change. Prefer to move and do something, not under strict control. Not sensitive to punishment, so it's not easy to feel afraid.

All employees who have introverted or extroverted personality types are expected to have high career development motivation. Furthermore, it can increase work motivation, solve various problems in the workplace, have a brilliant idea to support productivity and career development of the company, increase the effectiveness and efficiency of work as well as the quality and quantity of work. Following Government Regulation No. 46/2011 concerning Evaluation of the Performance of Civil Servants and Perka BKN Number 1/2013 concerning Provisions for the Implementation of Government Regulation No. 46/2011 concerning Performance Evaluation of Civil Servants, Civil Servants are required to develop Employee Performance Targets (SKP) as a basis for evaluating employee performance.

The development of employee performance targets aims to ensure the objectivity of civil service development based on the work performance system. In contrast, the Employee Performance Targets (SKP) are performance plans and targets that must be achieved by employees within a period of objective evaluation that can be measured and agreed upon by employees and their superiors.

Civil servants who have introverted and extroverted personalities can influence the performance (SKP) and Attitude. Then according to the background, this study will analyze the personality types of work performed in the City of Bogor Agriculture Service. The survey conducted on 40 people from the State Civil Apparatus (ASN) who served in the Agriculture Office of Bogor city, to determine personality types. The results of the mapping of employee personality types are then mapped with the results of employee performance evaluations for the past three years. The variable measured in this study is the Employee Performance Target (SKP) from the Agriculture Office of the state civil service (ASN) Bogor City, by observing four individual behaviours namely extrovert, extrovert + introvert, introvert + extrovert and extrovert $=$ introvert. This research shows the novelty of the importance of employee personality in improving performance and the existence of new concepts in the development of human resources based on the Pumping-HR Model.

\section{THEORETICAL REVIEW}

Personality. (Alwisol, 2019) concluded that according to Jung, personality includes thoughts, feelings and behaviour of a person. Personality will guide someone to adapt to the social environment and physical environment, both with awareness and with the unconscious. Personality guides people to adjust to the social and physical environment. 
According to Allport in (Sharma, 2016) "Personality is the dynamic organization within the individual of those psychophysical systems that determine its unique adjustment to its environment". (Alwisol, 2019) says that personality refers to a person's general nature, activity thoughts and feelings that influence systematically on his overall behaviour.

Personality is the behaviour that exposed to the social environment-the impression of the desired self that can be captured by the social environment. When personality becomes a scientific term, its understanding develops to be more internal, something that is relatively permanent, guides, directs and organizes human activities. Until now, there were still no formal restrictions on personality that got broad agreement on the personality expert environment. Variation of the definition is not just a variation on how to summarize the understanding, the definition model of the omnibus, integrative, substance or operational, but indeed the definition limits different concepts. Each personality expert gives their own description according to the paradigm they believe in and the focus of analysis of the theory they develop.

Personality is a dynamic arrangement that is hidden within a person which is a system that will create a characteristic arrangement of behaviour, thoughts, and feelings of a person (Ford, 2019). Personality is a unique and dynamic psycho-physical entity that contains habits and attitudes that are very useful in dealing with and adjusting the demands of one's life and life (Simanjuntak, 2018). Associated with differences in personality types, Jung classifies personality into two kinds, namely extroverted and introverted personality types (Keh and Cheng, 2019). Eysenck also distinguishes personality into two types, namely introverts and extroverts, where each of the patterns of action possessed by introverted and extroverted personalities is different and contradictory (Suryabrata, 2015). According to (Nurjanah et al., 2016), employee personality has a positive and significant effect on employee engagement.

Introvert-Extrovert. According to Jung in (Alwisol, 2019), introverts lead individuals to subjective experiences, satisfying oneself to dark world and privacy where reality is present in the form of observations, tends to be solitary, reserved or inhospitable, even antisocial. In general, introverts are often instinctual and busy with their own internal world.The results of (Eskandarpour and Mohammadzadeh, 2016) found that there was an influential correlation between personality types of introverts and extroverts with job satisfaction. According to (Asl et al., 2017) that task-based activities have a significant effect on experimental groups performances, but it has more impact on extrovert than introvert learners.

Based on daily behaviour, humans can be group into 21 self-portraits (types) (Ramly, 2014), namely: (1) Sanguine Popular (Sp), (2) CholericStrong (Sk), (3) Phlegmatic Peace (Pd), (4) MelancholicPerfect (Ms.), (5) SanguineStrong (Sk), (6) Sanguine Peace (Sd), (7) Sanguine Perfect (Ss), (8) Choleric popular (Kp), (9) Choleric Perfect (Ks), (10) Choleric Peace (Kd), (11) Phlegmatic Popular (Pp), (12) Phlegmatic Perfect (Ps), (13) Phlegmatic Strong (Pk), (14) Melancholic Strong (Mk), (15) Melancholic Popular (Mp), (16) Melancholic Peace (Md), (17) Sanguine master (SM), (18) Choleric Master (KM), (19) Phlegmatic Master (PM), (20) Melancholic Master (MM), (21) Master Altruist (MA). Introverted and extroverted personalities affect a person's achievements. Samand, Sailan, \& Lio's research results (2019) show 
that introverted students have better speaking achievement than extroverted students. The results also revealed that introverts are personalities that have better writing skills compared to extroverts (Qanwal and Ghani, 2019).

Performance. In 2014 the Government of the Republic of Indonesia perfected an evaluation of civil servant performance. They were initially using DP3 to become a pattern and mechanism for preparing and evaluating Employee Performance Targets (SKP). It regulated in Government Regulation Number 46 of 2011 concerning Performance Evaluation of Civil Servants consisting of SKP and attitudes and implemented effectively on January 1, 2014. Employee Performance Targets (SKP) are plans and performance targets that must be achieved by employees within a period of objective evaluation. They can be measured and agreed upon by employees and their superiors (Government Regulation Number 46/2011).

In general, assessments using the Employee Performance Target (SKP) approach are more productive and more objective, measurable, accountable, participatory, and transparent. This approach has educational value because the assessment results are openly communicated and can directly measure productivity and the final results of the work of employees of the state civil service (ASN). Performance Appraisal (PPK) of the State Civil Apparatus based on Government Regulation Number 46 of 2011. Evaluation of Civil Servants Work Performance is carried out by the Appraisal Officer once in 1 year (end of December of the year/end of January of the following year), which consists of $60 \%$ SKP element and the element of Work Behavior (Attitude) weighs $40 \%$.

Table 1. The Government Employees (ASN) Work Performance Value Table expressed as a number

\begin{tabular}{c|l|c|c}
\hline No & \multicolumn{1}{|c|}{ Interval } & Ouput & Likert Scale \\
\hline 1 & $91-100$ & Very good & 5 \\
\hline 2 & $76-90$ & Good & 4 \\
\hline 3 & $61-75$ & Enough & 3 \\
\hline 4 & $51-60$ & Less & 2 \\
\hline 5 & $50-$ come down & Bad & 1 \\
\hline
\end{tabular}

Source: (Agriculture Office of Bogor City, 2018)

Results showed that two motivational constructs, learning orientation and performance orientation play a major role in the manager's job performance. In addition, the relationship between personality traits and motivational constructs was observed: Extraversion, conformity, awareness, and emotional stability were found to have a significant relationship with the construct of motivation (Mukherjee and Bhat, 2018).

Pumping-HR Model. Pumping-HR Model is a learning concept that is used in HR training and development programs as a learning approach model. Pumping HR models are intellectual works that are produced through a 15-year HR development journey. The concept of learning pumping HR models is, as shown in Figure 1 below. 
Figure 1. Concept of Learning Pumping-HR Model (Ramly, 2019)

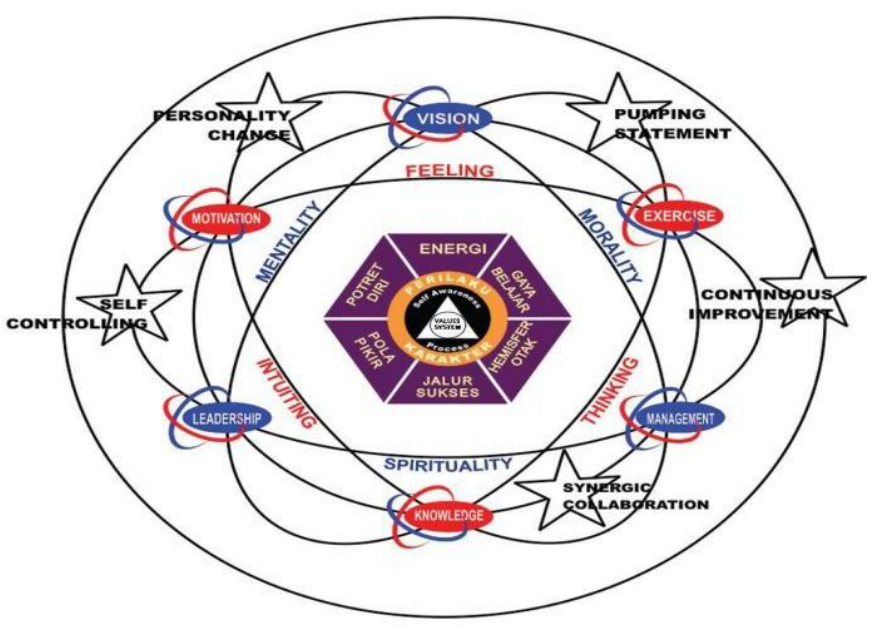

According (Ramly, 2016) Pumping HR Model consists of 3 main foundations, namely pumping HR principle, Pumping HR Competency and Pumping HR Action. Pumping HR Model is supported by management theories and human behaviour such as (1) a good tree parable consisting of roots, stems and fruit/leaves, (2) relies on the principles of the milky way model (solar system) which consists of the centre of the orbit, the orbital point and the orbital line, (3) relies on Iceberg's theory which shows three human realms, namely the unconscious, the conscious and the conscious, (4) relies on modern theories of human grace, namely the senses, intuition, and heart.

In the concept of learning Pumping-HR model, personality is one of the Key Indicators (KI) of the Pumping Principle (the principle of success). According to (Ramly, 2014), personality is a person's behaviour and success character. The behaviour of something that is easily seen and often changes, while the character of something that remains (genuine) in a person from birth. Characters that have appeared in a person are called behaviour. According to (Wikipedia, 2019), Personality is the way an individual reacts and interacts with other individuals. In this interaction, it involves elements of behaviour and related individual characters.

PERSONALITY $=$ BEHAVIOR + CHARACTER

Note: (1) Personality is a combination of visible and invisible human nature. Behaviour is a visible trait, and character is a hidden trait

Pumping models contain important assets that are not visible (intangible) that are needed by individuals and organizations, namely three principles, twelve competencies and five steps of action. The elements of values, competencies and actions that exist in the intended HR model pumping structure, as shown in Table below: 
Table 2. Important Assets in the Concept of Learning Pumping-HR Models (Ramly, 2019)

\begin{tabular}{|c|c|c|c|}
\hline \multirow[b]{2}{*}{ Success Principle } & \multicolumn{2}{|c|}{ Competency } & \multirow[b]{2}{*}{ Action } \\
\hline & Main & Support & \\
\hline \multirow{6}{*}{$\begin{array}{l}\text { 1. Values System } \\
\text { 2. Self Awareness } \\
\text { Process } \\
\text { 3. Personality }\end{array}$} & 1. Vision & 7. Mentality & \multirow{6}{*}{$\begin{array}{l}\text { 1. Statement } \\
\text { 2. Personality Change } \\
\text { 3. Self Controlling } \\
\text { 4. Network- } \\
\text { Collaboration } \\
\text { 5. Continuous } \\
\text { Improvement }\end{array}$} \\
\hline & 2. Leadership & 8. Morality & \\
\hline & 3. Management & 9. Spirituality & \\
\hline & 4. Knowledge & 10. Intuiting & \\
\hline & 5. Motivation & 11. thinking & \\
\hline & 6. Exercise (skill) & 12. Feeling & \\
\hline
\end{tabular}

Source: (Ramly, 2019)

The relationship between personality types, such as Extras, conformity, awareness, and emotional stability, was found to have a significant relationship with the construct of motivation. Two of the personality traits, extraversion and conscientiousness, are related to learning orientation and performance orientation (Mahlamäki et al., 2019). The results also showed that the intellectual, emotional, spiritual, and physical intelligence of employees at the cement company were on average quite high and met the competency and performance standards in the satisfactory and excellent categories (Oktaviani et al., 2019).

\section{METHODOLOGY}

The type of research carried out is Ex Post Facto Research which means, research conducted after what will be investigating happens. Ex post facto research aims to trace back, if possible, what are the factors that cause something to happen (Widarto, 2013). The sampling technique in this study uses probability random sampling. This technique is a sampling technique that provides equal opportunities for each element (member) of the population selected to become a sample. Here is a research model;

Equation (SKP): $\mathrm{Y} 1=\beta 0+\beta 1 \mathrm{D} 1+\beta 2 \mathrm{D} 2+\beta 3 \mathrm{D} 3+\mathrm{e} 1$

Note:

Y1 = is the dependent variable, namely Employee Performance Targets (SKP).

$\beta 0=$ is the first parameter, $\beta 1$ is the second parameter,

$\beta 2=$ is the third parameter and $\beta 3$ is the third parameter of the unknown regression.

D1 = an independent variable that represents extrovert behaviour,

D2 = an independent variable that represents the behaviour of Extrovert + Introvert,

D3 = an independent variable that represents the behaviour of Introvert + Extrovert. Extroverted = Introverted variable is a comparison variable for other categories, $\mathrm{el}$ is error. 
Data processing conducted in this study uses the SPSS (Statistical Package for Social Science) application for windows. Based on the purpose of this study, several data analysis techniques were use, namely (1) Descriptive Analysis, (2) Anova Difference Test, (3) Advanced BNt Test, (4) Classic Assumption Test, (5) Normality Test, (6) Test heteroscedasticity, and (7) Concurrent Significant Test (Test F).

Descriptive analysis is an analysis of all research variables that can describe the characteristics of the data. The descriptive analysis includes frequency, average, standard deviation, maximum values and minimum values. In this study, the authors analyzed the data using the One Way ANOVA test. ANOVA One Way says if the data is distributed and homogeneous, where the normality test and the homogeneity test an included in the basic assumption test.

\section{ANOVA Test Hypothesis}

$\mathrm{H} 0: \mu 1=\mu 2=\mu 3=\mu 4=\mu$

$\mathrm{H} 1$ : there is a minimum pair of I, I 'where $\mu \mathrm{i} \neq \mu \mathrm{i}$.'

If the ANOVA test results produce a calculated $\mathrm{F}$ value higher than the $\mathrm{F}$ table or a probability value smaller than alpha $5 \%$, then rejecting $\mathrm{H} 0$ means that behaviour (personality) influences SKP and Attitude. Significant F-test results must furthermore test with tests that can differentiate between behavioural influences.

Researchers also use the LSD test (Least Significant Difference) or better known as the LSD test (Least Significance Different) is a method introduced by Ronald Fisher. This method makes the BNt value or LSD value as a reference in determining whether the average of the two treatments is statistically different or not. To calculate the cost of BNt or LSD, we need some data derived from the calculation of variance (ANOVA) that has been done before; The data is in the form of MSE and dfE. The formula for calculating BNt values is:

$$
B N t_{\alpha}=\left(t_{\alpha, d f_{e}}\right) \cdot \sqrt{\frac{2\left(M S_{E}\right)}{r}}
$$

Normality test is used to test whether, in the regression model, there is a normal distribution between the dependent variable and the independent variable. If the data distribution is normal or close to normal, then the regression model is good. To test whether the research sample is a standard distribution type, the Normal P-P plot regression test is used on the model being tested. The basis for decision making is: (1) If the data spread around the diagonal line and follows the direction of the diagonal line, the regression model meets the normality assumption, and (2) If the data spreads far from the diagonal line or does not follow the direction of the diagonal line, then this regression model does not meet the norms of normality assumptions.

Heteroscedasticity test occurs when the $\mathrm{Y}$ variance changes, because of the $\mathrm{X}$ variable changes, resulting in differences, because of the disturbance (ei) that arises in the regression function has a different variant. To check, the absence of heteroscedasticity, a Spearman rank correlation test can be used, which is to correlate the independent variables with absolute residuals. If the significance of the correlation results is more significant than $0.05(5 \%)$, then heteroscedasticity does not occur 
(Robbani, 2017).

According to (Ghozali, 2013), the F statistical test shows whether all independent or independent variables entered in the model have a joint influence on the dependent or dependent variable. F statistics used with the following decision-making criteria: (1) If the value of $\mathrm{F}>4$ (with a degree of confidence 0.05 ), then $\mathrm{H} 0$ is rejected and $\mathrm{H} 1$ is accepted. If the alternative hypothesis is accepted, then all the independent variables significantly influence the dependent variable. (2) Comparing the value of the results of $F$ with those calculated $F$. That based on the following decision making: (a) If F table> $\mathrm{F}$ count, then $\mathrm{H} 0$ is accepted and $\mathrm{H} 1$ rejected. Means there is no influence between independent variables on the dependent variable; (b) If $\mathrm{F}$ table $<\mathrm{F}$, then $\mathrm{H} 0$ is rejected and $\mathrm{H} 1$ is accepted. Means there is influence between independent variables on the dependent variable.

In the $t$ statistical test, the $t$ value will be compared with the $t$ table value; (1) If $t$ arithmetic> t table ( $\mathrm{Sig}<0.05$ ), then $\mathrm{Ha}$ is accepted and Ho is rejected. The independent variable influences the dependent variable. (2) If $t$ arithmetic <t table or probability> level of significance (Sig> 0.05), then $\mathrm{Ha}$ is rejected. If Ho is accepted, then the independent variable does not affect the dependent variable.

\section{THE RESULTS OF STATISTICAL TESTS}

Descriptive Statistics of Research Variables. Descriptive results described according to behavioural variable variables, namely Extrovert, Extrovert + Introvert, Introvert + Extrovert, and Extrovert $=$ Introvert. Following are the results of descriptive tabulations of variables Employee Performance Targets (SKP), as shown in Table 3.

Table 3. Results of Descriptive Descriptive Analysis Employee Performance Targets (SKP)

\begin{tabular}{c|l|c|c|c|c|c}
\hline \multicolumn{2}{c|}{ Variable } & N & Average & $\begin{array}{c}\text { Std. } \\
\text { deviation }\end{array}$ & Minimum & Maximum \\
\hline \multirow{4}{*}{ SKP } & Ekstrovert & 4 & 4.125 & 0.185 & 3.95 & 4.35 \\
\cline { 2 - 7 } & Ekstrovert + Introvert & 23 & 4.268 & 0.130 & 3.90 & 4.48 \\
\cline { 2 - 6 } & Introvert + Ekstrovert & 10 & 4.234 & 0.121 & 4.00 & 4.40 \\
\cline { 2 - 6 } & Ekstrovert = Introvert & 3 & 4.330 & 0.052 & 4.30 & 4.39 \\
\cline { 2 - 7 } & Total & 40 & 4.250 & 0.134 & 3.90 & 4.48 \\
\hline
\end{tabular}

Sourch: (Data processing results, 2019)

Descriptive analysis results in table 1 show for Analysis Employee Performance Targets (SKP) response on the type of extrovert with a total of 4 participants having an average value of 4.125, a standard deviation of 0.185 , a minimum amount of 3.95 and a maximum value of 4.35. Analysis Employee Performance Targets (SKP) response on the type of Extrovert + Introvert with 23 participants had an average cost of 4.268, the standard deviation of 0.130 , the minimum value of 3.90 and a maximum value of 4.48. Analysis Employee Performance Targets (SKP) responses on the type of Introvert + Extrovert with 10 participants had an average cost of 4.234, a standard deviation of 0.121 , a minimum value of 4.0 and a maximum value of 4.40. Analysis Employee 
Performance Targets (SKP) response on the type of Extrovert=Introvert with the number of participants as many as three people has an average value of 4,330, a standard deviation of 0.052 , a minimum amount of 4.30 and a maximum value of 4.39. Type: Extrovert $=$ Introvert and the lowest average is the type of Extrovert with an average cost of 4.125 .

Anova One Way Test Results. ANOVA test conducted to test the effect of personality types on Analysis Employee Performance Targets (SKP). ANOVA results can answer two things, namely, check the impact and see differences between personality types on Analysis Employee Performance Targets (SKP). Following are the ANOVA test results, as shown in Table 4.

Table 4. ANOVA Test Results

\begin{tabular}{l|l|r|r|r|r|r}
\hline \multicolumn{2}{c|}{} & $\begin{array}{c}\text { Sum of } \\
\text { Squares }\end{array}$ & df & $\begin{array}{c}\text { Mean } \\
\text { Square }\end{array}$ & F & \multirow{2}{*}{ Sig. } \\
\hline \multirow{3}{*}{ SKP } & Between Groups & .142 & 3 & .047 & \multirow{3}{*}{3.033} & \multirow{2}{*}{.034} \\
\cline { 2 - 5 } & Within Groups & .560 & 36 & .016 & \\
\cline { 2 - 5 } & Total & .702 & 39 & & & \\
\cline { 2 - 4 } & Within Groups & .921 & 36 & .026 & & \\
\cline { 2 - 4 } & Total & 1.247 & 39 & & & \\
\hline
\end{tabular}

Source: (Data processing results, 2019)

The results of the two parameters, namely,Analysis Employee Performance Targets (SKP), are significant.

\section{BNt Further Test Results}

Table 5. Results of BNT follow-up Test Variable Employees Performance Targets (SKP)

\begin{tabular}{l|c|c}
\hline \multicolumn{1}{c|}{ Type of Behavior } & Average & Subset \\
\hline Ekstrovert & 4.125 & $\mathrm{a}$ \\
\hline Ekstrovert + Introvert & 4.268 & $\mathrm{~b}$ \\
\hline Introvert + Ekstrovert & 4.234 & $\mathrm{ab}$ \\
\hline Ekstrovert $=$ Introvert & 4.330 & $\mathrm{~b}$ \\
\hline
\end{tabular}

Source: (Data processing results, 2019)

BNT further test results in table 5 show a significant average difference between the types of behaviour of Extrovertsand Extroverts + Introvertsand Extroverts = Introverts. In contrast, the kind of action of Introvert + Extrovert is not significantly different. For the types of behaviour, Extrovert + Introvert, Extrovert $=$ Introvert and Introvert + Extrovert are not significantly different. If concluded, the kind of behaviour that produces the best SKP is Extrovert = Introvert, and the smallest and another type of behaviour is Extrovert. 
Figure 2. Results of Residual Normality Test Against Employees Performance Targets (SKP)

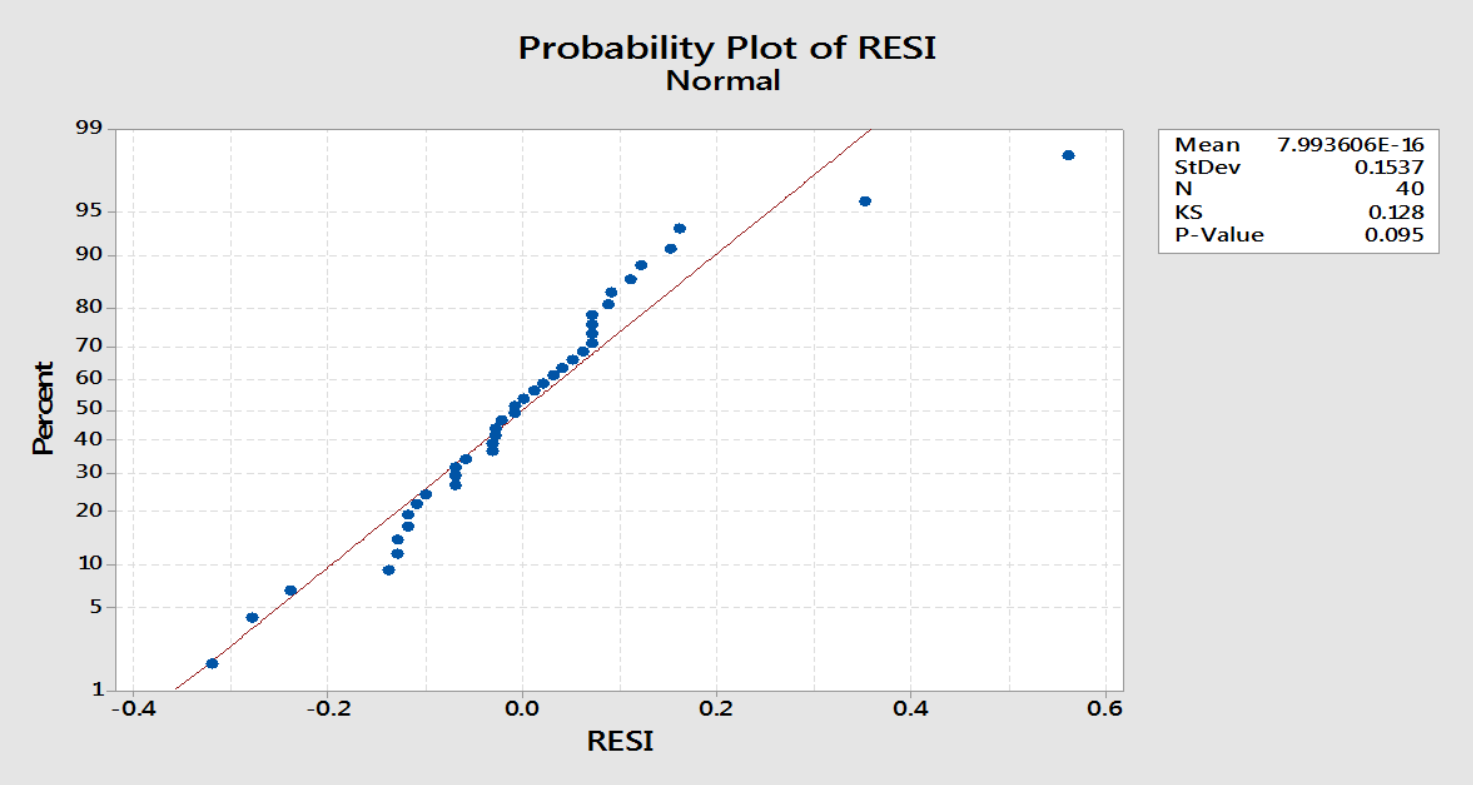

Source: (Data processing results, 2019)

Normality test results show a probability value (0.095). A probability value $(0.095)>$ alpha $5 \%$ means that the assumption of a reasonablespread of residuals is fulfilling.

\section{Homoscedasticity Test Results}

Figure 3. Homoscedasticity Test Results Against Employees Performance Targets (SKP)

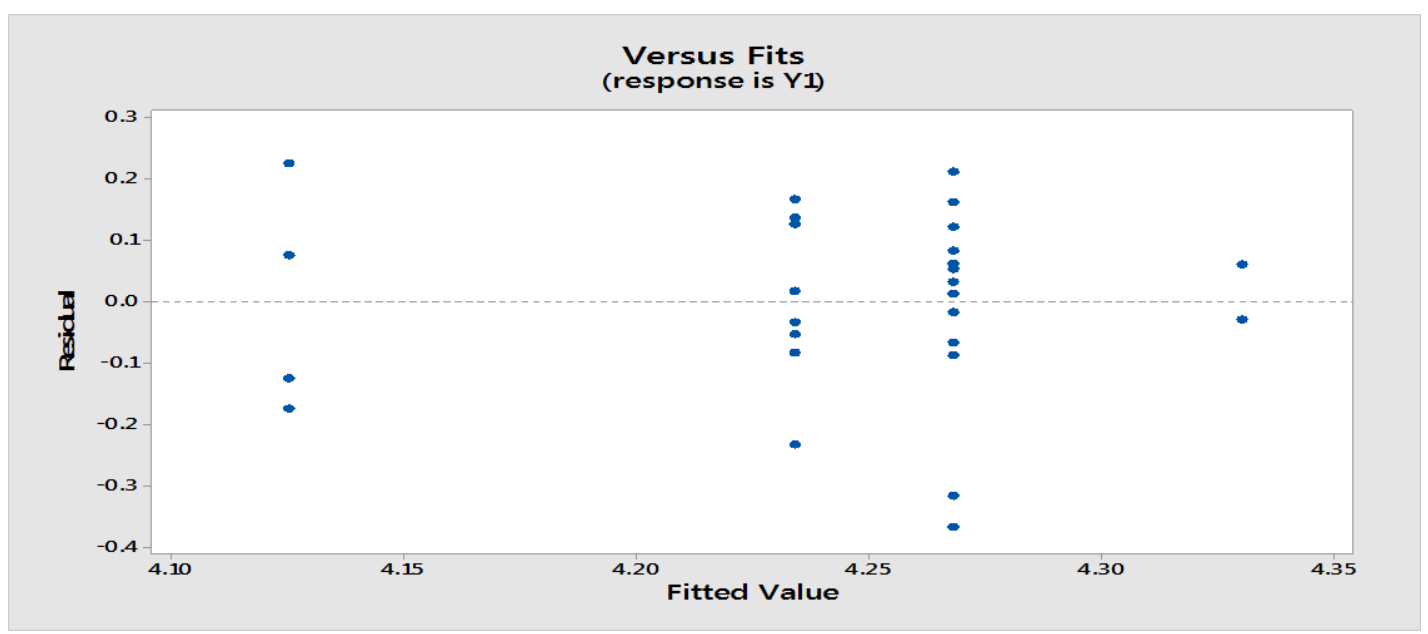

Source: (Data processing results, 2019)

The results of the data distribution showed that the distribution of data patterns did not form either linear or quadratic models. So it can be concluded already fulfilling 
the assumption of Homoscedasticity.

\section{F Test Results}

Table 6. F test results

\begin{tabular}{l|c|c|c|c|c}
\hline \multicolumn{1}{c|}{ Source } & DF & Adj SS & Adj MS & F-Value & P-Value \\
\hline Regression & 3 & 0.09157 & 0.03052 & 3.80 & 0.034 \\
\hline Error & 36 & 0.61013 & 0.01695 & & \\
\hline Total & 39 & 0.70170 & & & \\
\hline
\end{tabular}

Source: (Data processing results, 2019)

In table $6, F$ test results show the value of probability $(0.034)$ is smaller than alpha $5 \%$, meaning all independent variables importantly influence the dependent variable.

Coefficient of Determination. The coefficient of determination of $13.05 \%$ means that the diversity that can be explained by the type of behaviour factors towards Employees Performance Targets (SKP) is $13.05 \%$. In comparison, the remaining $86.95 \%$ is explained by other factors outside the model, as shown in Table 7.

Table 7. Results of Determination Coefficient Tests on Employees Performance Targets (SKP)

\begin{tabular}{c|c|c|c}
\hline S & R-sq & R-sq(adj) & R-sq(pred) \\
\hline 0.130185 & $13.05 \%$ & $5.80 \%$ & $0.00 \%$ \\
\hline
\end{tabular}

Source: (Data processing results, 2019)

\section{T-Test Results}

Table 8. Results of T-Test Against Employees Performance Targets (SKP)

\begin{tabular}{c|c|c|c|c}
\hline Term & Coef & SE Coef & T-Value & P-Value \\
\hline Constant & 4.3300 & 0.0752 & 57.61 & 0.000 \\
\hline Extrovert & & & & \\
\hline $\mathbf{1}$ & $\mathbf{- 0 . 2 0 5 0}$ & $\mathbf{0 . 0 9 9 4}$ & $\mathbf{- 2 . 0 6}$ & $\mathbf{0 . 0 4 7}$ \\
\hline $\begin{array}{c}\text { Extrovert + } \\
\text { Introvert }\end{array}$ & & & & \\
\hline 1 & -0.0622 & 0.0799 & -0.78 & 0.442 \\
\hline $\begin{array}{c}\text { Introvert + } \\
\text { Extrovert }\end{array}$ & & & & \\
\hline 1 & -0.0960 & 0.0857 & -1.12 & 0.270 \\
\hline
\end{tabular}

Source: (Data processing results, 2019) 


\section{DISCUSSION}

Descriptive statistical results on employee performance targets (SKP) show that of the four types of employee personality types, the highest average value is Extrovert = Introvert, and the lowest average is Extrovert type with an average cost of 4,125. ANOVA test results support these data that there are significant differences between types of behaviour towards SKP. ANOVA test results showed a probability value (0.034) smaller than alpha 5\%; there is a minimum pair of the kinds of action that results in a significantly different mean SKP value. This type of behaviour has a significant influence on SKP.

The results of BNT further tests can be concluded that the kind of behaviour that produces the best SKP is Extrovert = Introvert and the smallest and different from the other response is Extrovert.

The multiple regression results show that besides the significant coefficient D1 is 0.2050; it means that the average difference of employee performance targets (SKP) between Extrovert types is smaller than 0.02050 than the ordinarykind of Extrovert = Introvert. This personality type means that all negative coefficient values indicate that the sort of behaviour, namely Extrovert $=$ Introvert, which has the most significant influence on the SKP variable.

Test the effect of an extrovert on Employees Performance Targets. T-test results show that extrovert is significant to employee performance targets (SKP) because it has a probability value (0.047) smaller than alpha 5\%. The coefficient of an extrovert is -0.2050 , meaning that the average difference of Employees Performance Targets (SKP) between types of Extrovert behaviour is smaller than 0.02050 than the ordinarykind of Extrovert = Introvert

Test the Effect of Extrovert + Introvert on Employees Performance Targets. T-test results show that Extrovert + Introvert not significant to SKP because it has a probability value (0.442) more substantial than alpha 5\%. The meaning of insignificant can explained that there is no significant difference in the average SKP between the types of behaviour of Extrovert + Introvert with Extrovert = Introvert. Negative coefficient sign of -0.0622 means the average SKP type of behaviour Extrovert $=$ Introvert. Greater than the average SKP type of behaviour Extrovert + Introvert.

Test the Effect of Introvert + Extrovert on Employees Performance Targets. T-test results show that Introvert + Extrovert not significant to SKP because it has a probability value (0.270) more substantial than alpha 5\%. The meaning of insignificant can explained that there is no significant difference in the average SKP between the types of Introvert + Extrovert behaviour and the kinds of Extrovert $=$ Introvert behaviour. Negative coefficient sign of -0.0960 means the average SKP type of behaviour Extroverted $=$ Introverted. More significant than the average SKP type of Introvert + Extrovert behaviour.

Personality Type in Pumping-HR Model. In the concept of pumping-HR Model, there are five types of personality as a source of energy in activities, namely (1) introverted 
personality, (2) extrovert personality, (3) introvert + extrovert personality, (4) Extrovert + Introvert personality, (5) Personality Introvert = extrovert. The results of this study to the five personality types influence employee motivation and performance.

According to the pumping-HR model concept, personality is an essential element that functions as a building foundation or like the roots of a tree. Of the five personality types mentioned in the Pumping-HR model, certain behaviours occur. Introvert personality types will cause employee work behaviour in the category of melancholy, phlegmatic and or a combination of both. As well as extrovert personality types will lead to sanguine, choleric work behaviour or a combination of both. From the results of this study, it found that fundamental differences in employee performance in principle could be due to differences in personality types. Even though employees see to be dominated by the same personality type, but when viewed in detail, they differ from each other due to the various types of behaviour and character they have. Sanguine and choleric have the same kind of personality, extrovert domination. Both become different in perspective and approach because of differences in behaviour in detail.

\section{CONCLUSION}

Extrovert $=$ introverted personality type gives a more significant influence on performance (SKP) The Agriculture Office of Bogor City. There is a substantial difference between personality types and performance (SKP) employees The Agricultural Office of Bogor City.

Extrovert $=$ Introvert personality type yields the best average of civil Employees Performance Targets (SKP) The Agriculture Office of Bogor City. Whereas Extrovert personality types produce the lowest percentage of civil servant work performance (SKP) of the Agriculture Office of Bogor City.

Work performed in a Unit of Regional Apparatus Work (SKPD), it is preferred to place extroverted $=$ introvert personality types, especially in essential positions.

\section{REFERENCES}

Alwisol. (2019). Psikologi Kepribadian (Edisi Revisi). Malang: UMM Press.

Asl, H. D., Razavi, S. D., and Vaskehmahaleh, M. T. (2017). Task-Based Activities on EFL Learners Argumentative Writing with a Focus on Introvert vs. Extrovert Learners. Journal of Applied Linguistics and Language Research, 4(6), 183-191.

Dinas Pertanian Kota Bogor. (2018). Pedoman Penilaian Sasaran Kinerja Pegawai (SKP) dan Attitude Pegawai Dinas Pertanian Kota Bogor. Bogor: UPT Pemotongan Hewan Dinas Pertanian Kota Bogor.

Eskandarpour, M., and Mohammadzadeh, J. (2016). Evaluation of the Relationship between Personality Type (Extrovert-Introvert) with Job Satisfaction of Bank Employees Case Study: Private Banks in the City of Karaj. International Journal of Humanities and Cultural Studies (IJHCS) ISSN 2356-5926, 1(1), 524-535.

Ford, D. H. (2019). Humans as self-constructing living systems: A developmental perspective on behaviour and personality. Routledge.

Ghozali, Imam. (2013). Aplikasi Analisis Multivariate Dengan Program SPSS 19 Edisi Kelima. Badan Penerbit Universitas Diponegoro. Semarang 
Judge, T. A., and Zapata, C. P. (2015). The Person-Situation Debate Revisited: Effect of Situation Strength and Trait Activation on the Validity of the Big Five Personality Traits in Predicting Job Performance. Academy of Management Journal, 58(4), 1149-1179.

Keh, S. S., and Cheng, I. (2019). Myers-Briggs Personality Classification and Personality- Specific Language Generation Using Pre-trained Language Models. arXiv preprint arXiv:1907.06333.

Kurniawan, M. F., dan Stanislaus, S. (2016). Perilaku Pro-sosial ditinjau dari Tipe Kepribadian Introvert dan Ekstrovert (Studi pada Mahasiswa Psikologi UNNES). Intuisi: Jurnal Psikologi Ilmiah, 8(3), 195-199.

Mahlamäki, T., Rintamäki, T., and Rajah, E. (2019). The Role of Personality and Motivation on Key Account Manager Job Performance. Industrial Marketing Management, 83, 174-184.mance in jobs involving interpersonal interactions. Human performance, 11(2-3), 145-165.

Mukherjee, U., and Bhat, V. (2018). Personality as Predictor of Organisational Citizenship Behaviour: A Study in the Indian Information Technology Industry. MANTHAN: Journal of Commerce and Management, 5(2), 1-20.

Nurjanah, R., Rofaida, R., dan Suryana, S. (2016). Kepribadian Karyawan dan Budaya Organisasi: Faktor Determinan Keterikatan Karyawan (Employee Engagement). Jurnal Manajemen, 20(2), 310-324.

Oktaviani, A. R., Haerani, S., Asdar, M., \& Ismail, M. (2019). Individual Intelligence as One of Competency Assessments and Performance of Employees in State-Owned Cement Enterprises. In 3rd International Conference on Accounting, Management and Economics 2018 (ICAME 2018). Atlantis Press.

Peraturan Pemerintah Nomor 46 (2011) tentang Penilaian Prestasi Kerja PNS dan Perka BKN Nomor 1/2013 tentang Ketentuan Pelaksanaan PP Nomor 46/2011 tentang Penilaian Prestasi Kerja PNS, ).

Qanwal, S., and Ghani, M. (2019). Relationship Between Introversion/Extroversion Personality Trait and Proficiency in ESL Writing Skills. International Journal of English Linguistics, 9(4).

Ramly, A. T. (2016). Pengembangan Sumber Daya Manusia yang Unggul Berbasis Pumping-HR Model. Jurnal Manajemen (Edisi Elektronik), 7(2), 138-151.

Ramly, A. T. (2014). Pumping Talent, Memahami Diri, Memompa Bakat. Pumping Publisher, Bogor.

Ramly, A.T. (2019). Evaluation of Pumping HR (Human Resources) Model-Based Training Program on Human Resources Development at Bogor Agricultural University (IPB). Integrated Journal of Business and Economics, 3(2), 153-163.

Robbani, C. (2017). Pengaruh Motivasi Kerja dan Lingkungan Kerja Terhadap Kinerja Karyawan (Studi Kasus Pada Warung Susu Segar Shi-Jack di Surakarta) (Doctoral dissertation, Universitas Muhammadiyah Surakarta).

Samand, S. M., Sailan, Z., and Lio, A. (2019). Analysis on the Relationship of ExtrovertIntrovert Personality and Students' Speaking Performance in English Study Program of Halu Oleo University. Journal of Language Education and Educational Technology (JLEET), 4(1).

Sen, C., and Dulara, S. (2017). Job characteristics and performance: The mediating role of job crafting. The International Journal of Indian Psychology, 5(1), 66-74. 
Sharma, V. P. (2016). Influence of Personality Traits and Self-Concept on Performance as an Individual or as a Team at the College Level. Retrieved from http://www.kheljournal.com/archives/2016/vol3issue5/PartA/3-3-68-692.pdf (29.02.2020).

Simanjuntak, H. V. (2018). Pengaruh Job Embeddednes dan Komitmen Organisasi Serta Kepribadian Terhadap Kepuasan Kerja Pegawai Dan Kinerja Pegawai Pada Universitas Trunajaya Bontang. KINERJA, 15(2), 82-99.

Suryabrata (2015). Psikologi Kepribadian Edisi Ke-1. Jakarta: Rajawali Pers.

Widarto, (2013). Penelitian Expost Facto. Retrieved from http://staffnew.uny.ac.id/ upload/131808327/pengabdian/8penelitian-ex-post-facto.pdf/24.02.2020). 